\author{
ارزيابى مدل استباطى خاك- سرزمين (SOLIM) در نقشهبردارى خاك \\ براساس منطق فازى در كاشان \\ الهام مهرابى گوهرى "، حميدرضا متين فرَّ ورح ا... تقى زاده مهرجردى

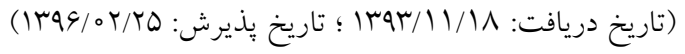

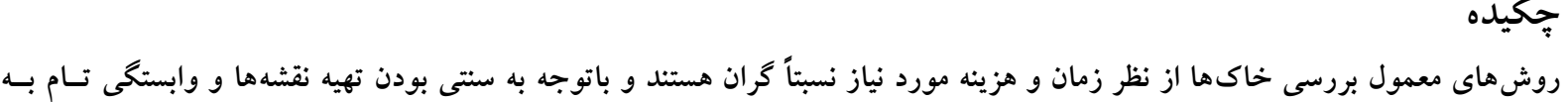

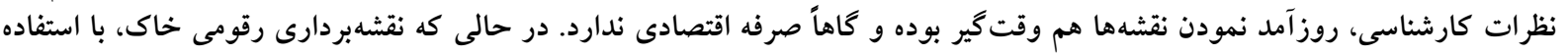

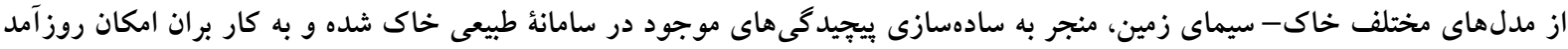

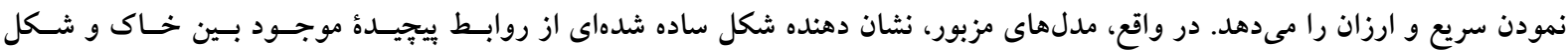

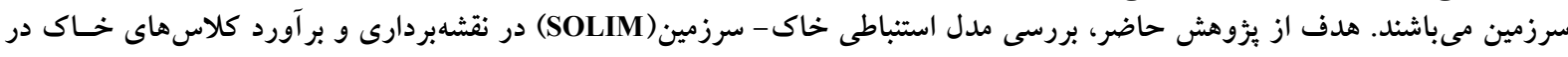

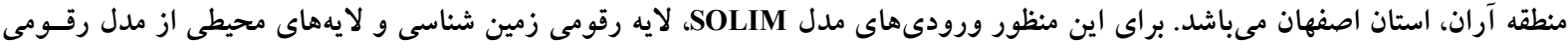

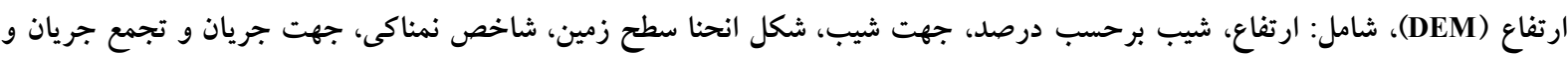

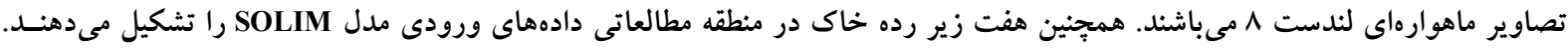

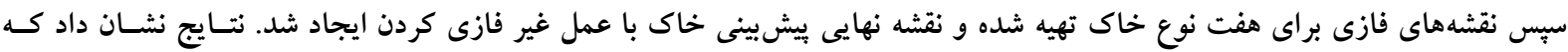

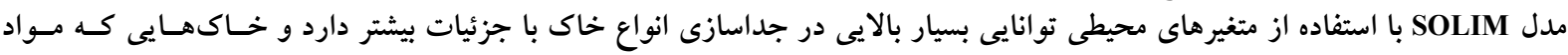

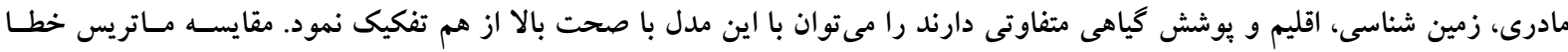

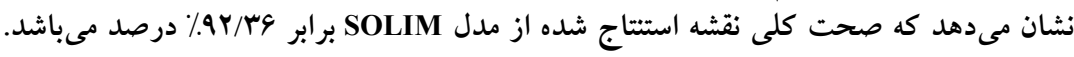

وازمهاى كليدى: نقشهبردارى رقومى خاك، مدل رقومى ارتفاع، منطق فازى، مدل SOLIM

\footnotetext{
ا.دانشكده كشاورزى، دانشگاه بيام نور و دانشجوى دكترى مهندسى علوم خاك، دانشگاه لرستان

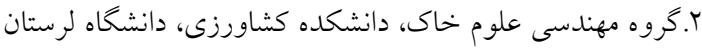

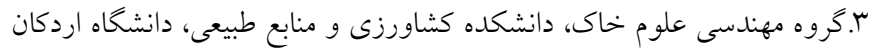

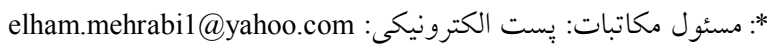


خاك و بسط آن براى مكانهاى نمونهبــردارى نشـــه مسىباشـــ

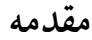
(9). معمولاً خاك شناسان توسعه روابط خاك- سيماى سرزمين

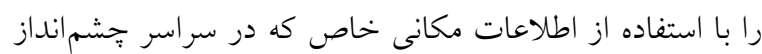
براى مكانهاى نمونهبردارى نشده قابل تعميم باشــ را تـرجيح

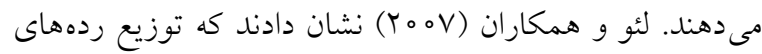

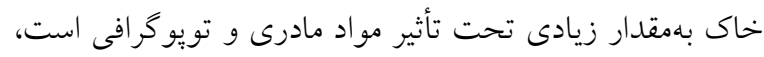

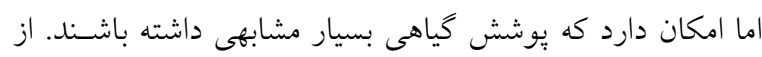

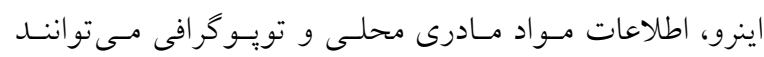
بهعنوان متغيرهاى كمكى خاكى براى نقشهبردارى ردههاى خاك

در مناطق كوهستانى محلى استفاده شوند( (11).

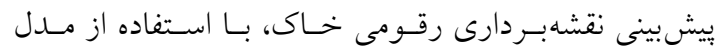

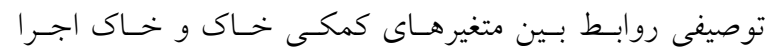
مىشود. مدل سازى روابط كام كليدى است كـه سـزاوار توجــهـ

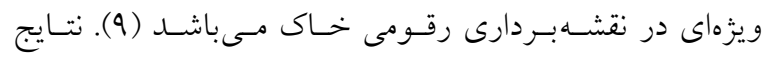

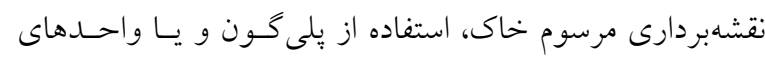

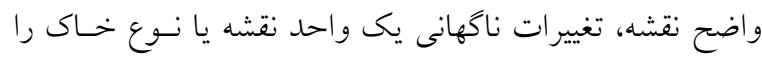

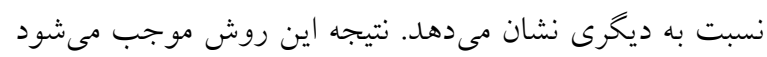

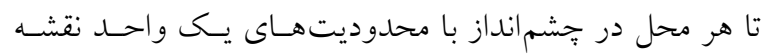

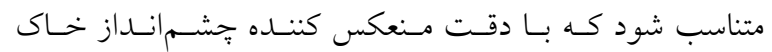

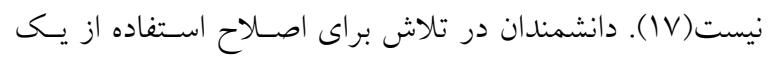

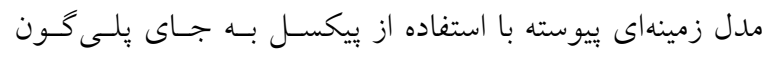

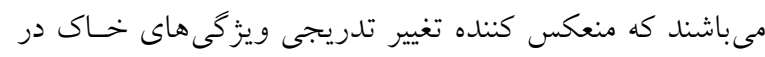

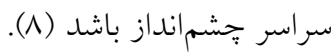

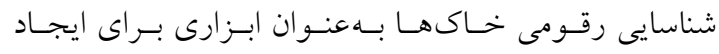

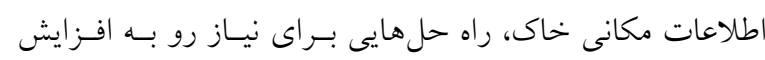
نقشههاى خاك با تفكيك مكانى بالا را تأمين مى كند. بنـابراين،

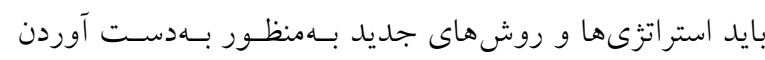
اطلاعات مكانى خاك با تفكيك مكانى بالا توسعـه يابـــ (19).

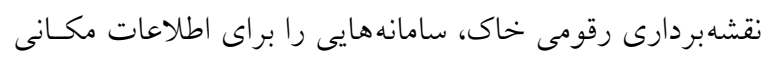

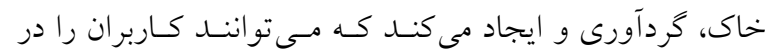

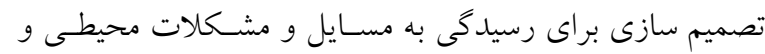

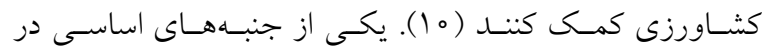

الكوى سنتى يا معمــول نقشـهـ بـردارى خـاك، براسـاس ميـزان

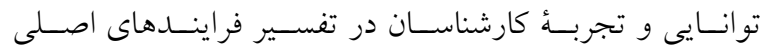
خاكسازى و فاكتورهـاى محيطى دخيـل در تشكيل سـيماى

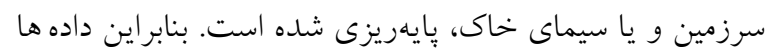

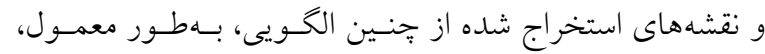

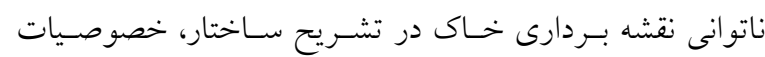

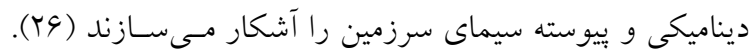

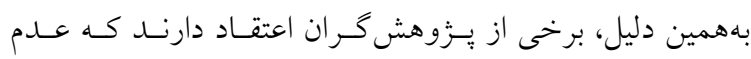

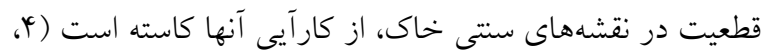

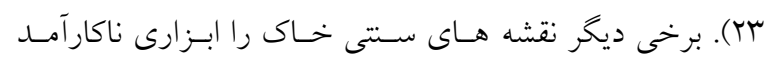

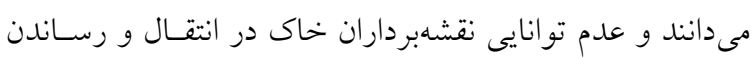
آشكار و صريح مدلهاى ذهنى خود را دليل اين ناكارآمدى بيان نمودهاند (YY) (1) (ن) محسدوديتهـاى موجــود در روشهـاى سـتنى (مرسـوم)

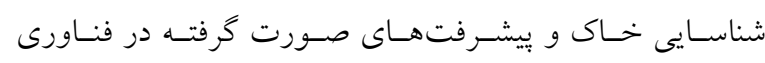

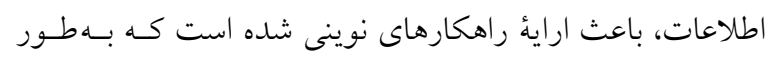

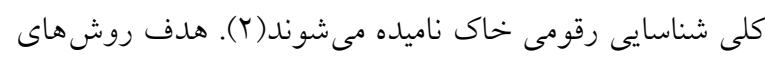

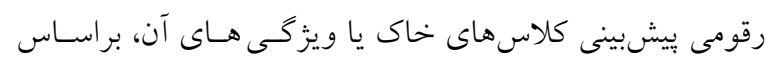

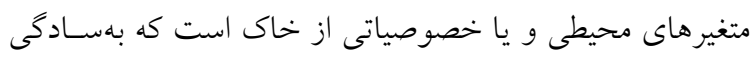

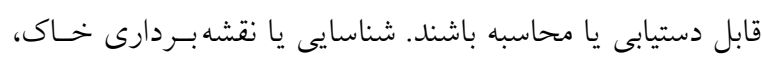

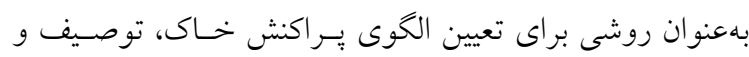

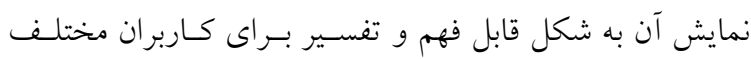

نقشه هاى خاك بِيه و اطلاعات محيطى اسـاس اطلاعـات

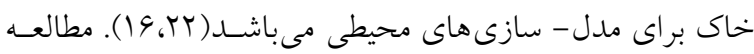

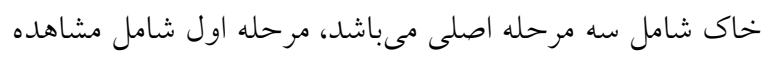
اطلاعات جانبى مانند عكس هاى هوايى، زمين شناسى و همـراه

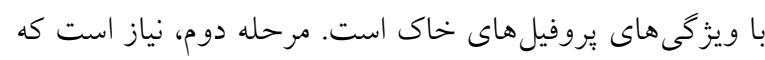

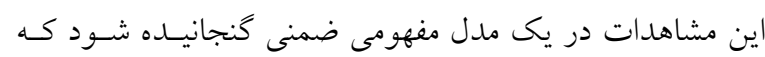
براى يى بردن به تنوع خاك ضرورى است. مرحله سوم استفاده

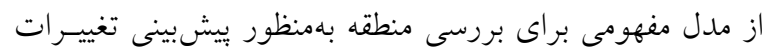




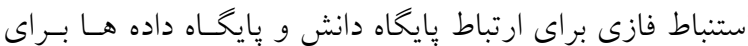
استخراج بردار تشابه خاك بهكار مىرود. مطالعــات زو و همكــاران (1999، 19001) نشــان داد كــــ نقشه هاى تهيـه شــده بـا اسـتفاده از مـدل SOLIM نسـبت بــه نقشههاى حاصل از روش سنتى شناسايى خاك، از دقت عمومى بالاترى برخوردار مى باشند(rآ، هT). از طرفى برآوردهاى انجام

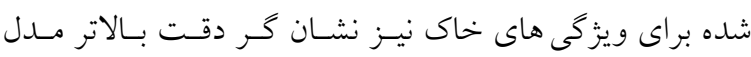
نسبت به روش هاى مرسوم بــودهانــد. زو و همكــاران SOLIM (199V) با مقايسة مدل SOLIM و روش سنتى، بهمنظور تخمين ضخامت افق A در منطقة كوهستانى غرب مونتانا، نتيجه گرفتند

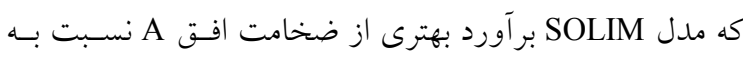
روش سنتى در دسترس قرار مى دهـــ جر اكـهـ در ايسن منطقـه،

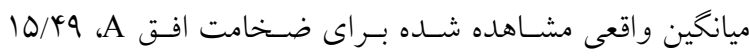
سـانتى متــر بــود و بر آوردهــاى مــدل SOLIM و روش سـتنى،

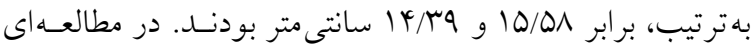
ديخر در جنوب غربى بروجن باقرى بيان داشت ارزيـابى نتـايج

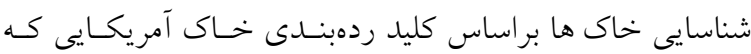
داراى معيارهاى سخت و صلب است، تا حدى مى تواند گمــراه كننده باشد؛ حـال آن كـه اسـتفاده از مـــل فـازى SoLIM كـهـ تغييريذيرى تدريجى خاكى ها را مد نظـر قـرار مسى دهـد، نمـود بهترى از واقعيت خاكها را بيان مى كند. بهطور كلى، در مناطقى كه اطلاعات و دانش مناسبى از روابط خاك-سرزمين موجـود باشد، مدل SOLIM براوردهاى قابل قبولى از ويزّىى هاى خاك و سرزمين را در اختيار قرار مىدهد. از آنجايى كه نقشه هاى يُستى و بلندى و مدل هـاى رقـومى ارتفاع تقريباً براى كل كشور موجود مىباشند و بهدليل وقت كير بودن و بالا بودن هزينه شناسايى و نقشـهـ بـردارى خــاك هــا بـهـ

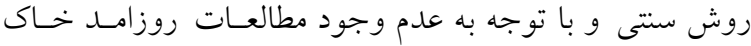
براى بخش كستردهاى از ايران، انتظار مىرود كه استفاده از مدل رقومى ارتفاع و ويزگگى هاى آن، بتواند كمك شايانى در بــــآورد كلاس هاى خاك و يا ويزگ كى هاى آنها در مناطق مختلف كشـور ارايه نمايد. هدف از يزوهش حاضـر، نقشـهـ بــردارى و بــرآورد
نقشهبردارى رقومى خاك، استفاده از مدلهاى مختلف بهمنظـور سادهسـازى يِيجيـــى هــاى موجــود در سـامانهُ طبيعى خـاك مسىباشـد. بـر ايسـن اسـاس، مــدل اسـتنباطى خــاك-سـرزمين بيانگر شكل ساده شدهاى از روابط بيجزيـده موجـود (SOLIM) بين خاى و شكل سرزمين مىباشند كه فرايندهاى تكاملى خاى و الكوى بر اكنش آن را نشان مىدهند (V). مــدل اسـتنباطى خــاك - سـرزمين يـا SOLIM از جملــه مدلهايى است كه بهمنظور غلبه بر محدوديتهــاى موجـود در روشهاى شناسايى سنتى خاى،توسط زو و همكـاران در سـال 1999 ارائه شده است. در اين مدل نقشهُ خـاك بـر خيايسة مــدل خاك- سرزمين ايجاد مى گردد. بدين معنـا كـه خــاك تـابعى از

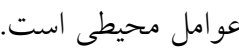
$S=f(E)$

كه در آن S و E به ترتيب، بيـانكر خـاك و متغيرهـاى محيطى هستند و f نشـاندهنــدهُ رابطـهُ خـاك - محسيط (مـدل خـاك سرزمين) مى باشد. براساس اين مدل، اگر ويزگگ هاى محيطى و رابطهُ خاك- سرزمين، براى يكى موقعيت شناخته شـده باشـــــ

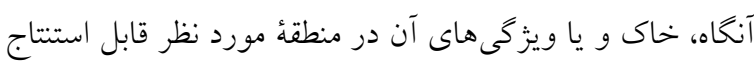
خواهند بود. اين مدل داراى سه جزء اصلى زير است: () مدل تشابه كه براى نمايش بيوسته خاكها كاربرد دارد، ايسن مدل، مبتنى بر منطق فازى مى باشد. بنابراين، هر بييكسل مى تو اند با درجات عضويت مختلف، به بيش از يك كلاس خاك تعلـق كيرد. Y) موتور استنباط فازى يا شيوه استباط خودكار كه با استفاده از مدل تشابه، انجام عمليات نقشهبردارى خاى را برعهده دارند. r) مجموعهُ روش هايى كه براى استنتاج نتايج اطلاعات خاى از مدل تشابه بهار مىروند. بهطور كلى، مدل SOLIM بـا درنظـر كرفتن محيط سازنده هر خاى و روابـط خـاى ســرزمين (كـهـ

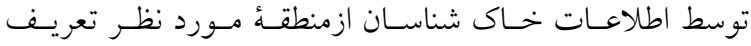
مى شوند)، اقدام به تشكيل يك بايخاه دانش مى كند. و ويثزى هاى محيطى منطقة مورد نظر (مانند مدل رقومى ارتفاع و ويزگگ هاى آن) در يك بايخاه دادههاى جغر افيايى نخهارى مىشوند. موتور 


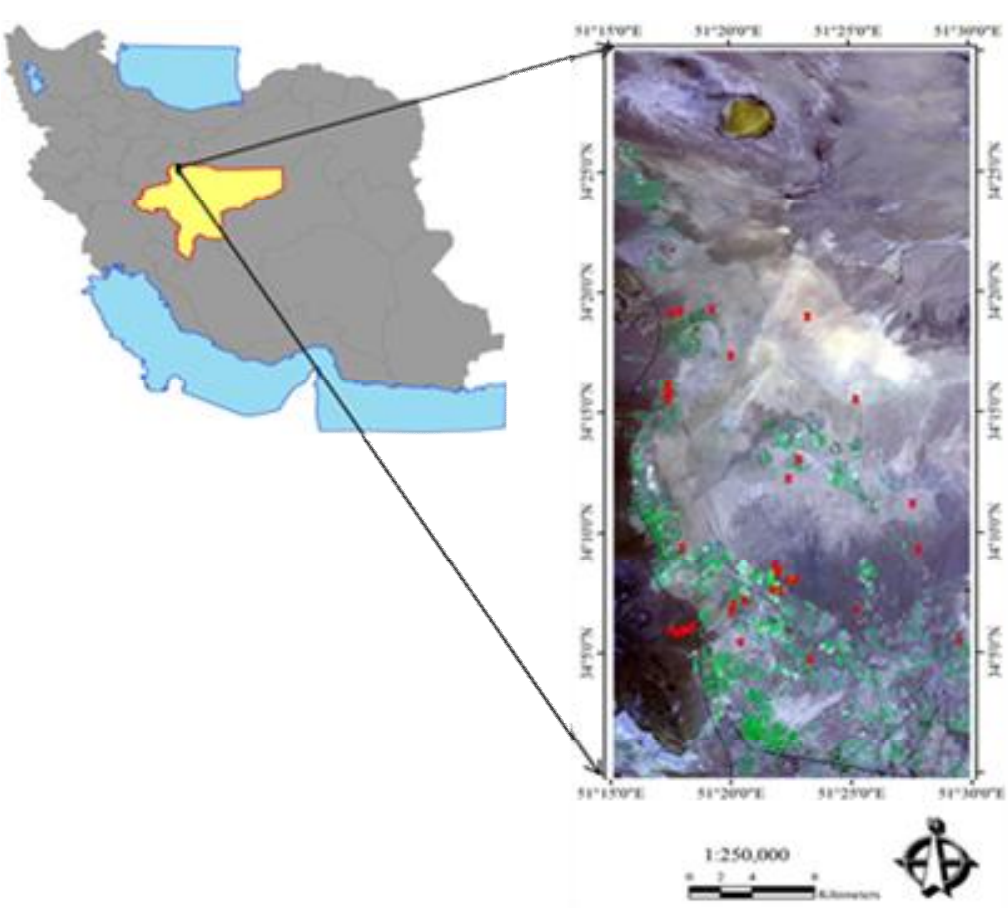

شكل ا. موقعيت منطقه موردمطالعه

كز ) مى باشد. با توجه به ميزان اندى بارندكى و عدم منـابع آب

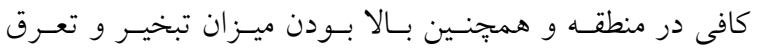
يتانسيل بهطور كلى يوشش كياهى منطقه فقير مى وباشد.

\section{نمونهبردارى خاك ومطالعات آزمايشخاهى} اطلاعات خاك جمــع آورى شـده از منطقــ مطالعـاتى، شـامل

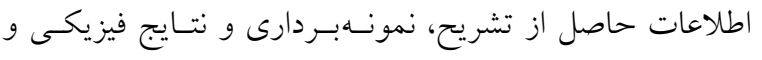

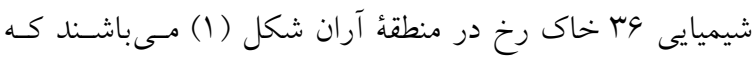

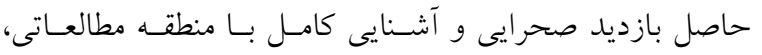
واحدها و اجزاء واحدهاى اراضسى ،حفــر بروفيـلهـا، تشـــيح

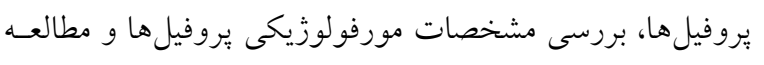

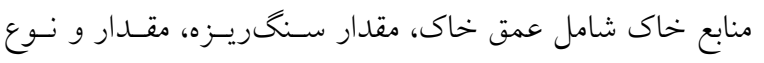
آهك، افق هاى فيزيكى و شيميايى مورد نياز شامل درصد ذرات

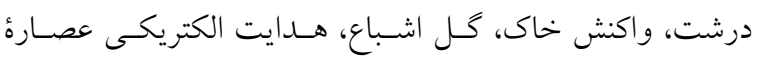

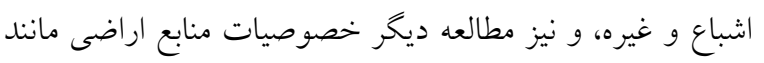

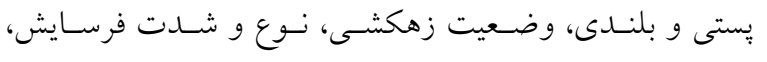

كلاسهاى خاك با استفاده از مدل اسـتنباطى خـاك- سـرزمين (SOLIM)

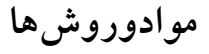

معرفى منطقة مطالعاتى محدوده مورد بررسى در استان اصفهان و شامل اراضى كاشان و

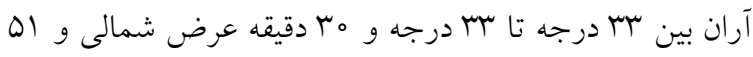

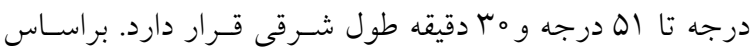

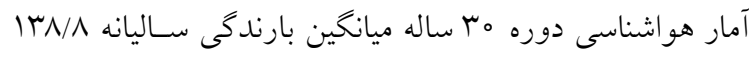
ميلى متر است، بارشها از آبان ماه شروع شــده و در خردادمادهـاه

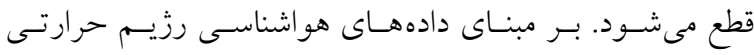

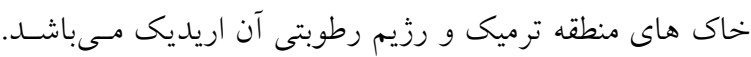
اين محدوده از اطراف توسط ارتفاعاتى كه بخشى از كـوهــاى

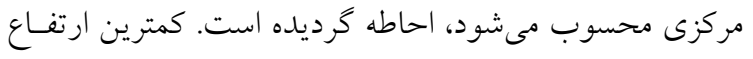

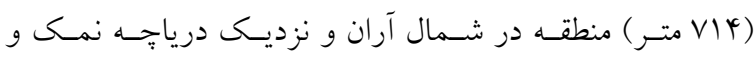

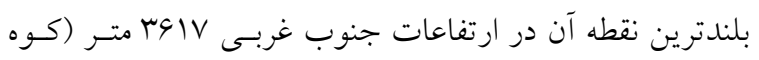




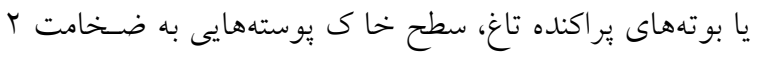

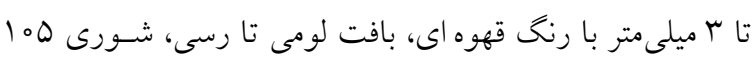

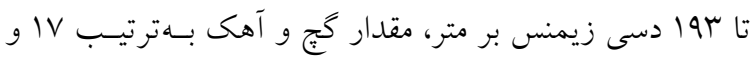
r/D در صد مىباشد.

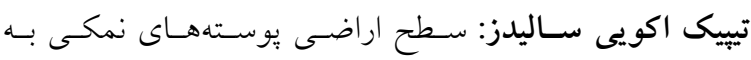
ضخامت تا ده سانتى متر، سطح اراضى مرطـوب و تيـره اسـت، بافت لومى تا لومىشنى، شورى بين 91 تا وسا دسى زيمنس بر

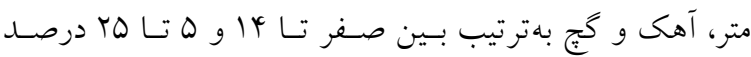

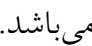
تيبيك تورى يسامنتز: اراضى با بوشـش كــم تـا متوسـط تـاغ،

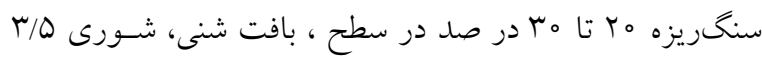
دسى زيمنس بر متر، مقدار آهك و گج بهترتيب با ب و Y درصد مىباشد.

\section{تهيئ دادههاى رقومى و بردازش آنها}

بهمنظور ايجاد لايههاى رقومى ورودى مدل، لايه رسـترى مــل

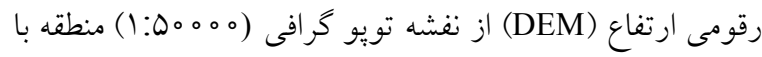
قدرت تفكيك مكانى هب متر تهيه گرديد و مورد اسـتفاده قـرار

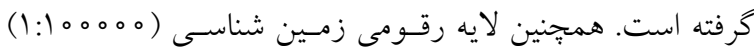
بهعنوان يكى از لايههاى ورودى مدل در محيط سامانه اطلاعات جغرافيايى توليد شد. در اين يزوهش جهـت توليـــ و يــردازش لايههاى مختلـف اطلاعـاتى از نـرمافزارهـاى ArcGIS، نسـخه

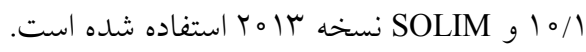
لايههاى ورودى مدل SOLIM، لايه رقومى زمين شناسى و

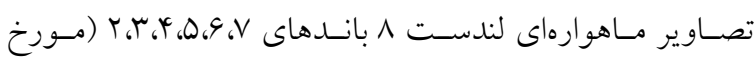
(Y0|Y/Y/T) روش تصوير به تصوير، تصحيح اتمسفرى به روش جسم سياه، بارز سازى به روش محاسبه تصوير رنكى كاذب و شاخصهاى كياهى و خاك انجام شد.

تصاوير خام سنجش از دورى هميشـه داراى خطاهـايى در مقادير ثبت شده براى بيكسل ها مى باشــند كـهـ بـهـ ايـن خطاهـا خطاى راديومتريك كفته مى شود. تصحيحات راديومتريك براى
يوشش گياهى و شيب كلى و جـانبى مسىباشـــد. تمـام خـاك رخهاى حفر شده، براساس راهنمـاى تشـريح و نمونسهبـردارى

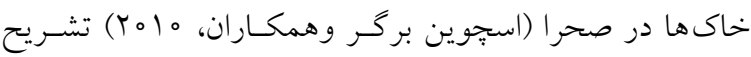
شدند و مطابق با كليد ردهبنـدى آمريكـايى خـاى طبقــبنــى كرديدند و درنهايت، از تمامى افقهاى زنتيكى آنها نمونهبردارى انجام گرفت. سبس آزمايشهاى بافت خاك و اجزاى آن، ميزان

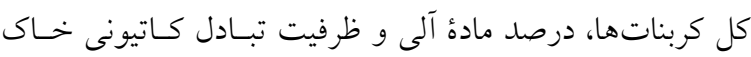
براساس روشهاى استاندارد بر روى نمونهها انجام كرفت و در

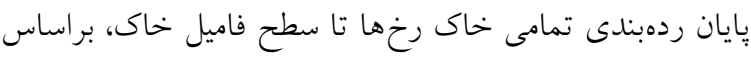
نتايج آزمايشخاهى و مطابق با كليد ردهبنـدى آمريكـايى خـاك نهايى گرديد كه در زير مشخصات زير ردههاى غالـب منطقه آورده شده است. تيبيك تورى فلوئنتز: باغات انار، آلو و زرد آلو با قدمت ها تا TO سال كه بر روى يُادگانههاى آبرفتى استقرار يافتهانـد، نقــاط معرف باغـاتى مسىباشـند كـه داراى بوشـش كـاملى از سـطح مىباشند. تيبيك هايلو كلســيدز: مخلـوط زراعـت هــاى برداشـت شـــه

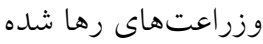
تيبيك هايلو زيّيسيدز: اراضى مرتعى با يوشش ينج تا ده درصد

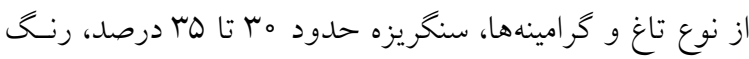
خاى سطحى قهوهاى مايل بنصورتى تا قهوهاى خيلى كم رنخ،

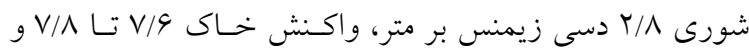

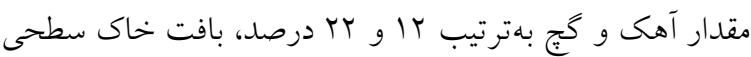
لو مى شنى تا شنى مىباشد . تيبيك تورى اورتنز: اراضى مرتعى با بوشش كيـاهى برنـــ بــه

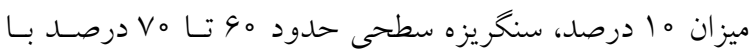
تركيب رنكى سياه مايل به قر مز Vo درصد، قرمـز ضـعيف درصد و خاكسترى تيره ده درصد و رنك ذرات خاك بين آنهـا قهوهاى مايل به قر مز تيره، بافت شنى لـومى تـا شـنى، شـورى

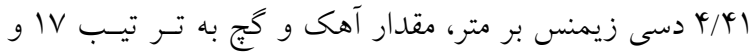
صفر درصد مىباشد تيبيك هايلوساليدز: اراضى لم يزرع تقريباً بدون يوشش گياهى 
معادل NDVI كمترى نسبت بهساير يوشش هاى سطحى اسـت.

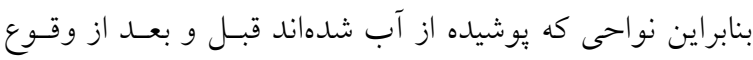

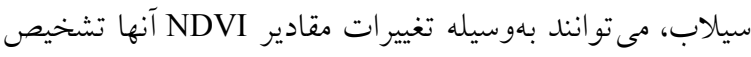

$$
\text { داده شوند. }
$$

لايههاى محيطى منتج شده از مدل رقومى ارتفـاع (DEM)،

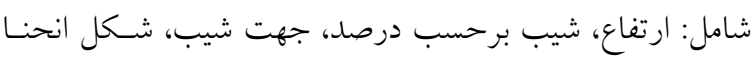

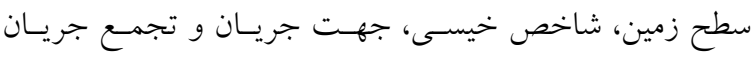

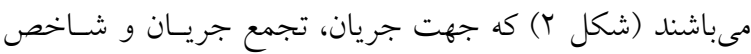
نمناكى و همجنين توليد لايه هاى عو ارض سطحى (ماننــ لايـه

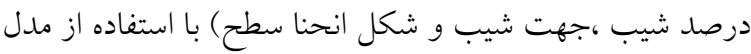

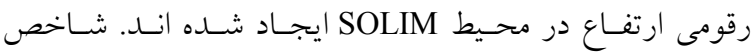

$$
\text { خيسى بلصورت زير محاسبه مى شود: }
$$

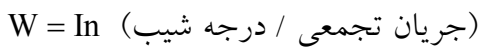

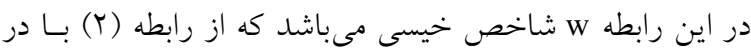
دست داشتن تجمع جريان و درجه شيب محاسبه مسى شـود. در

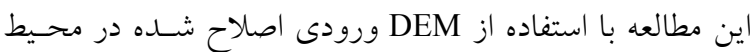
SOLIM الحوريتم جنند مسـير شـاخص خيسـى محاسـبه شــد.

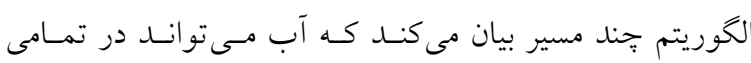

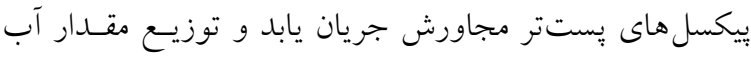

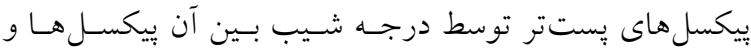

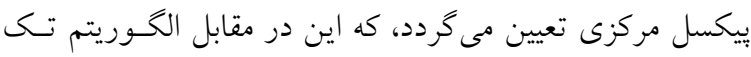

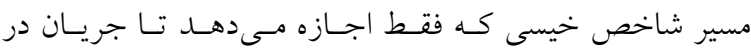
شديدترين جهت صورت مى گيرد، نتايج بهترى را ارائه مى دهد.

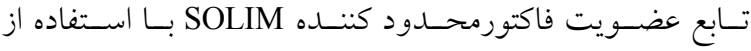
متغيرهاى كمكى زيست محيطى و متغيرهاى شكل زمسين بـراى

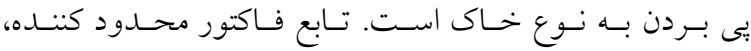
ييكربندى زيستمحيطى در يك محل خاص را براى سرىهاى خاك با هم مقايسه مى كنــد و حــاقل مقــدار بهينخـى در ميـان

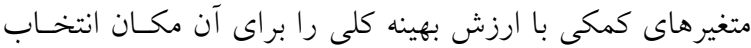
مدل SOLIM يكى تابع عضويت فـازى رسـترى بـراى هـر

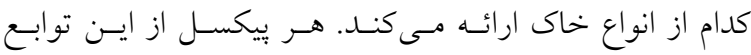

حذف دو نـوع خطـاى عمــده اتمسـفرى و دسـتخاهى بـهــار مىروند. تصحيحات اتمسفرى در سنجش از دور از ضـروريات

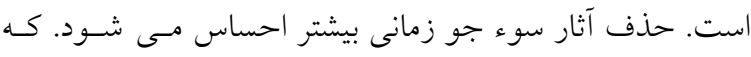

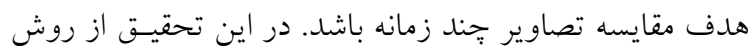
تفريق تيركى ها در تصحيح راديومتريك استفاده كرديم.

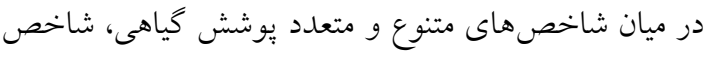

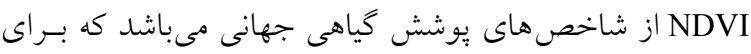

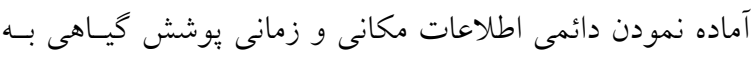

$$
\text { كار رفته مىشود. }
$$

\section{شاخص نرمال شده اختلاف يوشش گياهى(NDVI)}

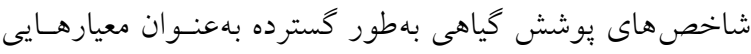

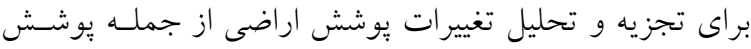

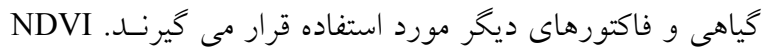

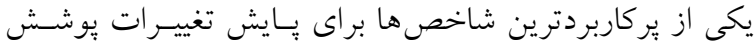

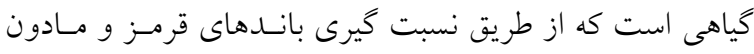

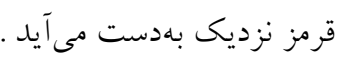

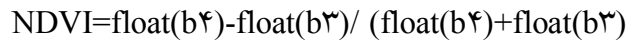

ץ float b4 باند float br باند : باند

NDVI

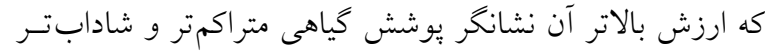
است. در اين شاخص فرض بــر ايـن اسـت كـه ناحيـهـ تحـت فئس

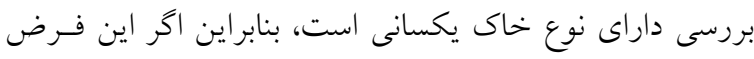

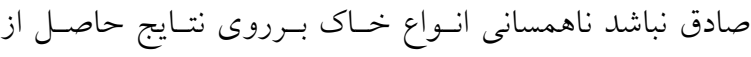

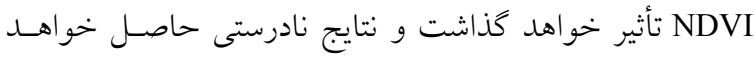

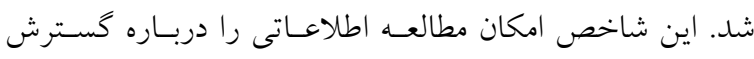

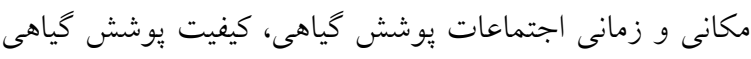

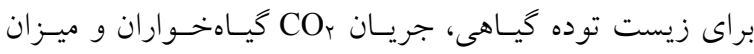
توسعه تخريب خاك را در اكوسيستمهاى متنوع مهيا مى جسـازد.

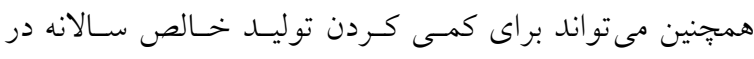

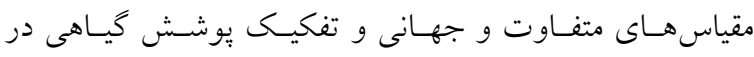
مقياس هاى قارهاى و جهانى به كار كرفته شود. آب داراى مقدئ مقدار 


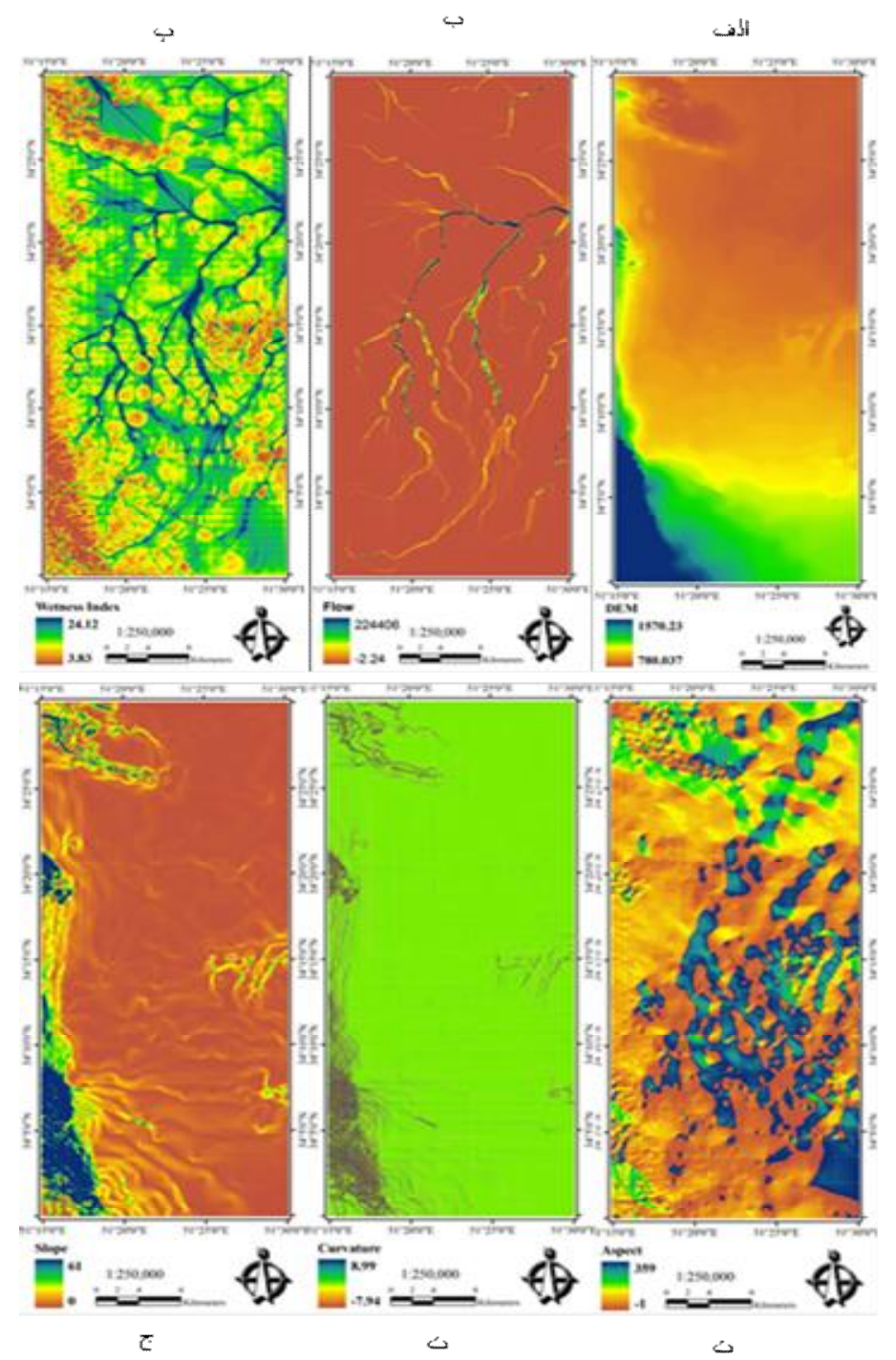

شكل r. الف) نقشه ارتفاع، ب) تجمع جريان، ب) شاخص خيسى منتج شده از مدل رقومى ارتفاع منطقه مورد مطالعه توسط

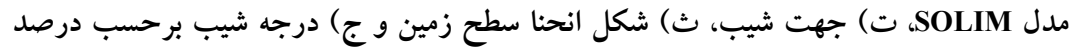

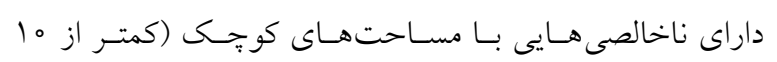

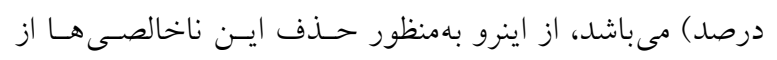

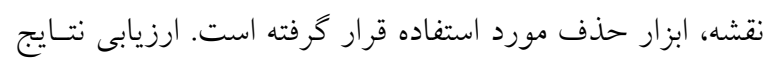

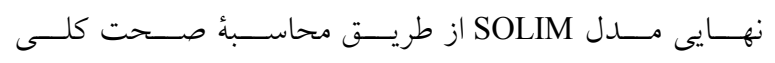

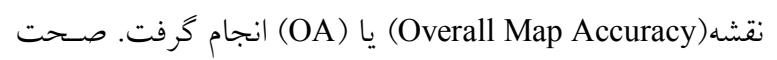

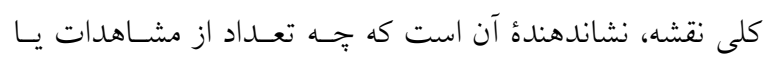

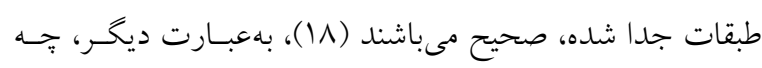

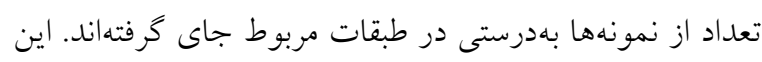

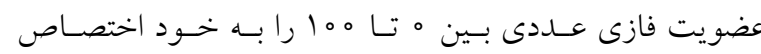

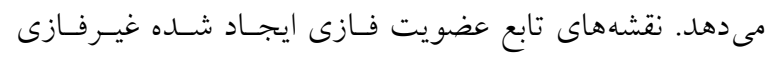
مىشوند. در طى فرايند غير فازى كردن، خاك با مقادير بيشسينه

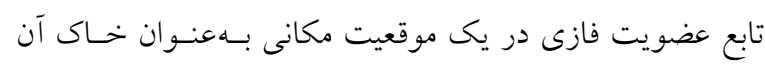

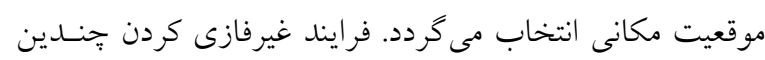

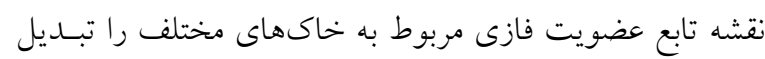

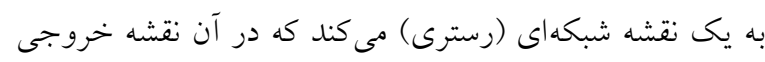

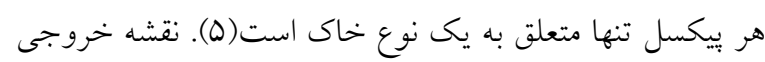




\begin{tabular}{|c|c|}
\hline \multicolumn{2}{|c|}{ ردهبندى براساس طبقبندى خاى آمريكايى } \\
\hline شماره يروفيل & زيررده \\
\hline 1,IYGTtGT,TY & تيبيك تورى اورتنتز \\
\hline هז, & تيبيك هايلو كلسيدز \\
\hline$r .96 r^{\circ}$ & تيبيك هايلو زييسيدز \\
\hline 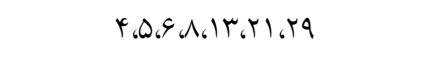 & تيبيك تورى فلوئنتز \\
\hline V & تيبيك تورى يسامنتز \\
\hline $\mid r_{6} I V$ & تيبيك اكويى ساليدز \\
\hline 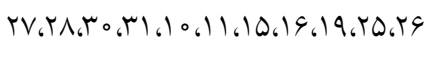 & تيبيك هايلو ساليدز \\
\hline
\end{tabular}

مطالعه صورت گرفت و صحت نقشه رقومى اين مدل با توجه بـه جدول ماتريس خطا كه توسط SOLIM محاسبه شد، برابـر وسر 9 و

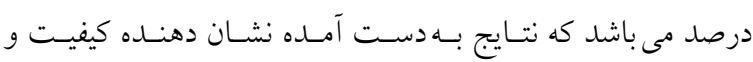
صحت نقشه رقومى خاك است. جدول (Y) مقايسه ماتريس خطـا نقشه غيرفازى حاصل از مــل SOLIM براسـاس سـطح زيـر رده براى تمامى خاك رخ هاى منطقه مورد مطالعه را نشان مىدهـد. در نقشه ايجاد شــه براسـاس مــل SOLIM ويزخ هـى هـاى مـؤثر در خاكسازى در هر منطقه يعنسى فاكتورهـايى جــون شـيب، ارتفـاع، زمين شناسى را مد نظر قرار مىدهيم و براساس ميـزان تـأثير ايسن فاكتورها واحدهاى خاى را جداسازى مى كنيم. بنـابراين واحسـهــا بهصورت جزئىتر در قسمتهاى مختلف براساس تفاوتهايى كـه

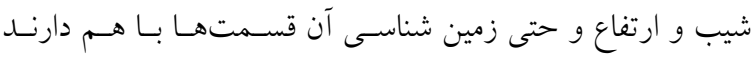
جداسازى مى شود و همجنـين بـا اسـفاده از تصـاوير مـاهوارهاى مى توان از لحاظ طيفى نيز خاكهـا را تفكيـك كـرد. امـا در تهيسه نقشه مرسوم كـه براسـاس نقشـهـ زمسين شناسـى و زئومورفلـوزى

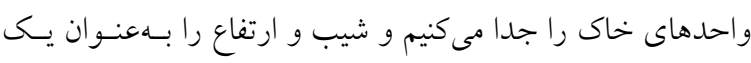

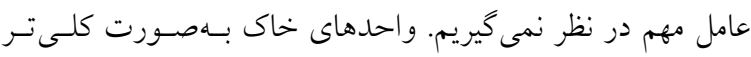
جدا مى شوند و به اين دليل است كـه نقشـه ايجـاد شــده از مـدل داراى دقت بالاترى در جداسازى واحدهاى خاى است. SOLIM خروجى SOLIM بهصورت بيكسـل يـا رسـتر مسىباشــ و مىتواند براى كاربران اطلاعـات خــاك بسـيار مفيـــ باشـــ. در روش مرسوم، نقشه خاك در قالب يلى گون ارائه مىشود كه هر
ويزگ گى، با تشكيل ماتريس خطا توسـط مــدل SOLIM و نقــاط كنترلى و براساس فرمول زير قابل محاسبه مىباشد (ه ا، ها). O.A $=\frac{\sum_{\mathrm{i}=1}^{\mathrm{e}} \text { Eij }}{\mathrm{N}}$

كه در آن e تعداد كلاسها، N تعداد كل بيكسل هاى معلوم، Eii اعضا قطرى ماتريس خطا و O.A. دقت كلى طبقهبندى مىباشد.

\section{نتايج و بحث}

جدول (1) نشانكر نتـايج ردهبنـدى هفـت زيـر رده خـاك غالـب موجود در منطقة مطالعاتى است. جدول مزبور، نمايانخر اين اسـت

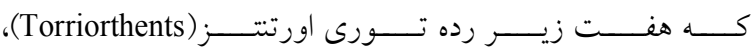
هايلوزّيبــيدز(Haplogypsids)، هــايلو كلسـيدز(Haplocalcids)، تورى فلـوئنتز (Torrifluvetns)، تـورى يسـامنتز(Torripsaments)،

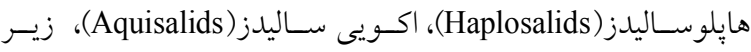
ردههاى غالب منطقه مىباشند. نشان مىدهد (شـكل هـاى بـ و باو و 0). در هر يك از اين نقشهها، رنخ تيرهتر بهمعنى عضويت فـازى بالاتر براى خاك مىباشد. نقشه بيشبينى نهـايى شـكل (ه) بـراى منطقه مورد مطالعه نقشه غيرفازى، نتايج SOLIM مى باشـد. نقشـهـ رقومى خـاك كـه بـهـوسـيله غيرفـازى كـردن ايجـاد شــده اسـت كلاسهاى با بالاترين مقــادير عضـويت فـازى بـراى هـر مـ متـر واحد سلول را به تصوير مى كشد. اعتبـار ســنى نقشـه اسـتخراج شده از مــل SOLIM بـا اسـتفاده از نتــاط كنترلسى منطقـه مـورد 


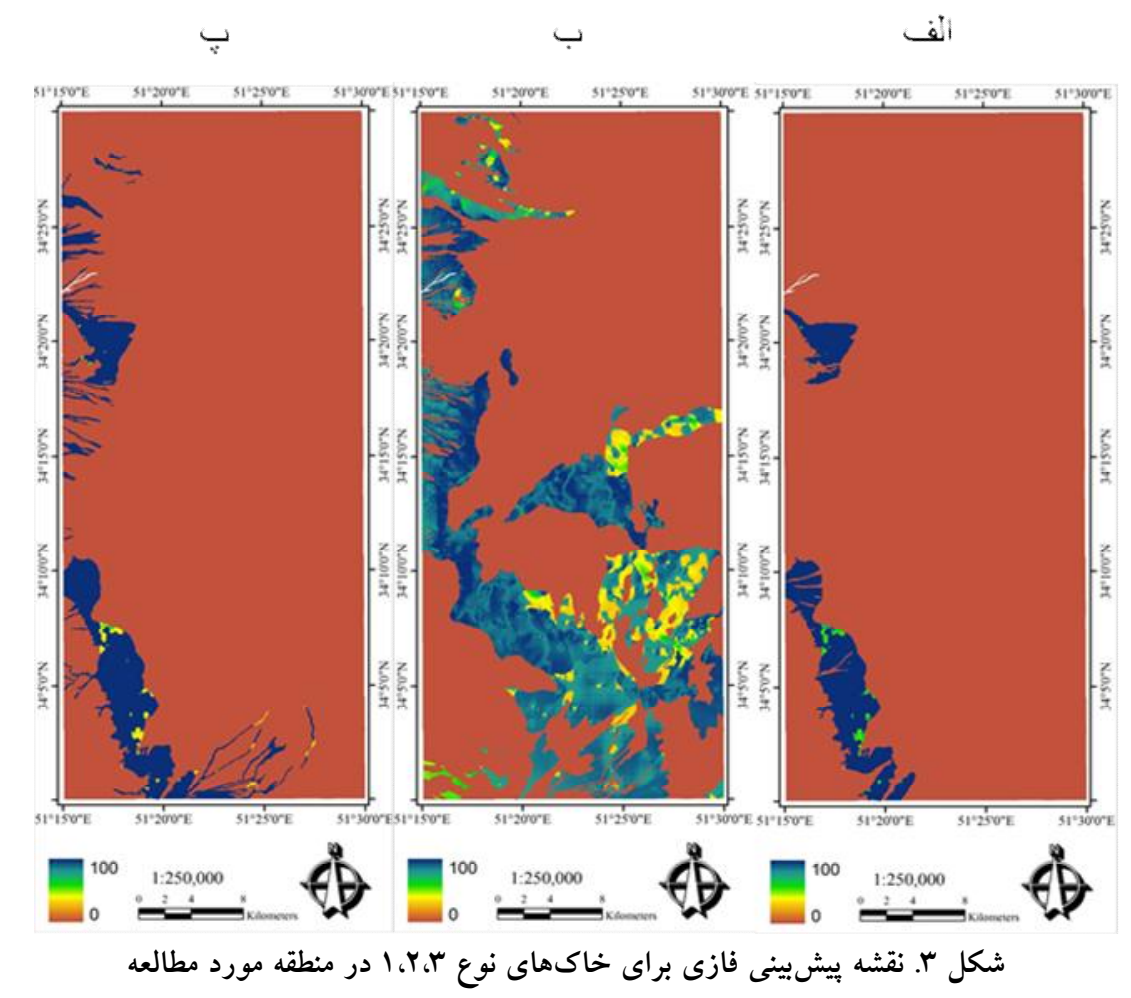

الف) خاى نوع ا (تورى اورتنتز)، ب) خاك نوع r (هايلو كلسيدز) و ب) خاى نوع r (هايلوزيّيدز)
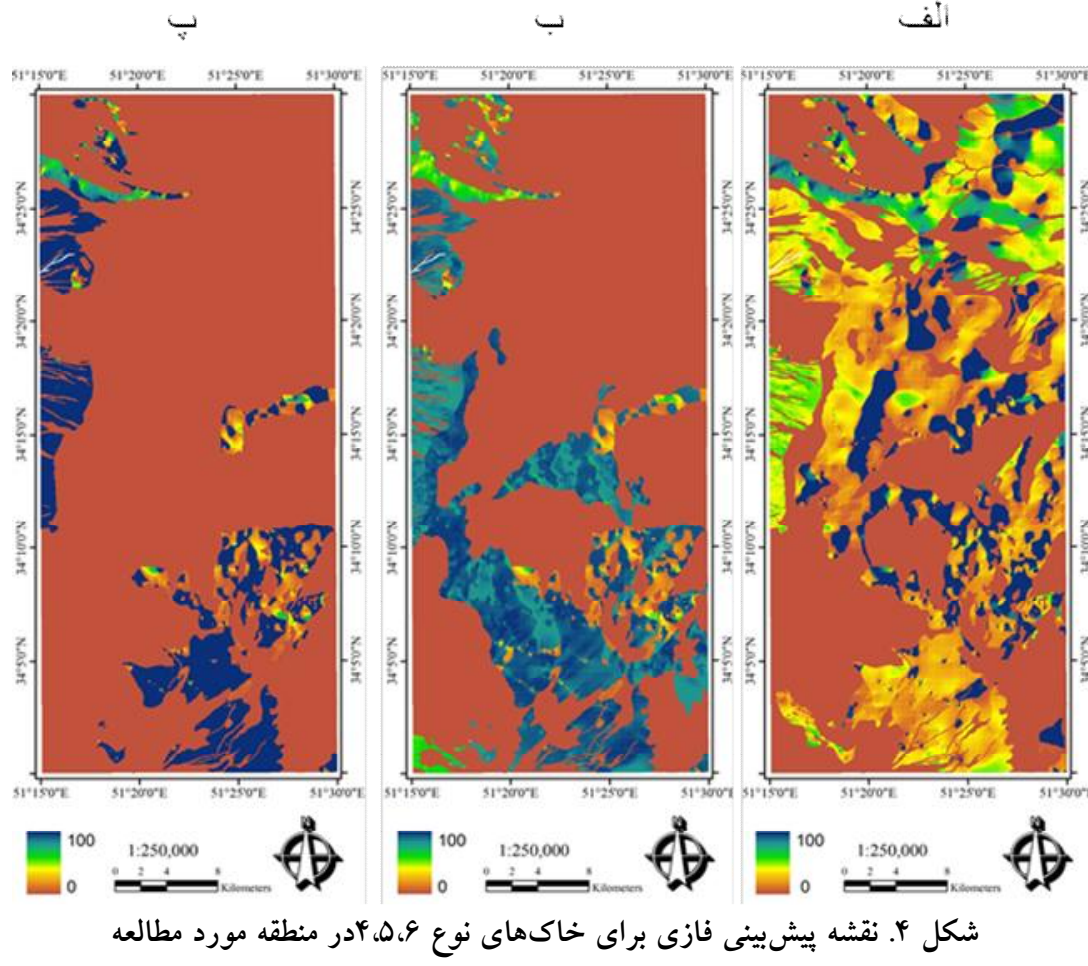

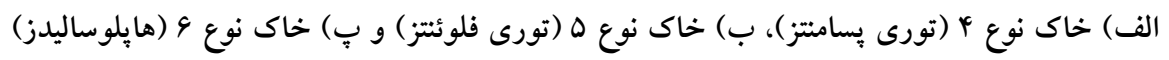




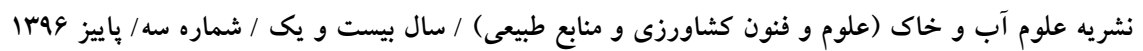

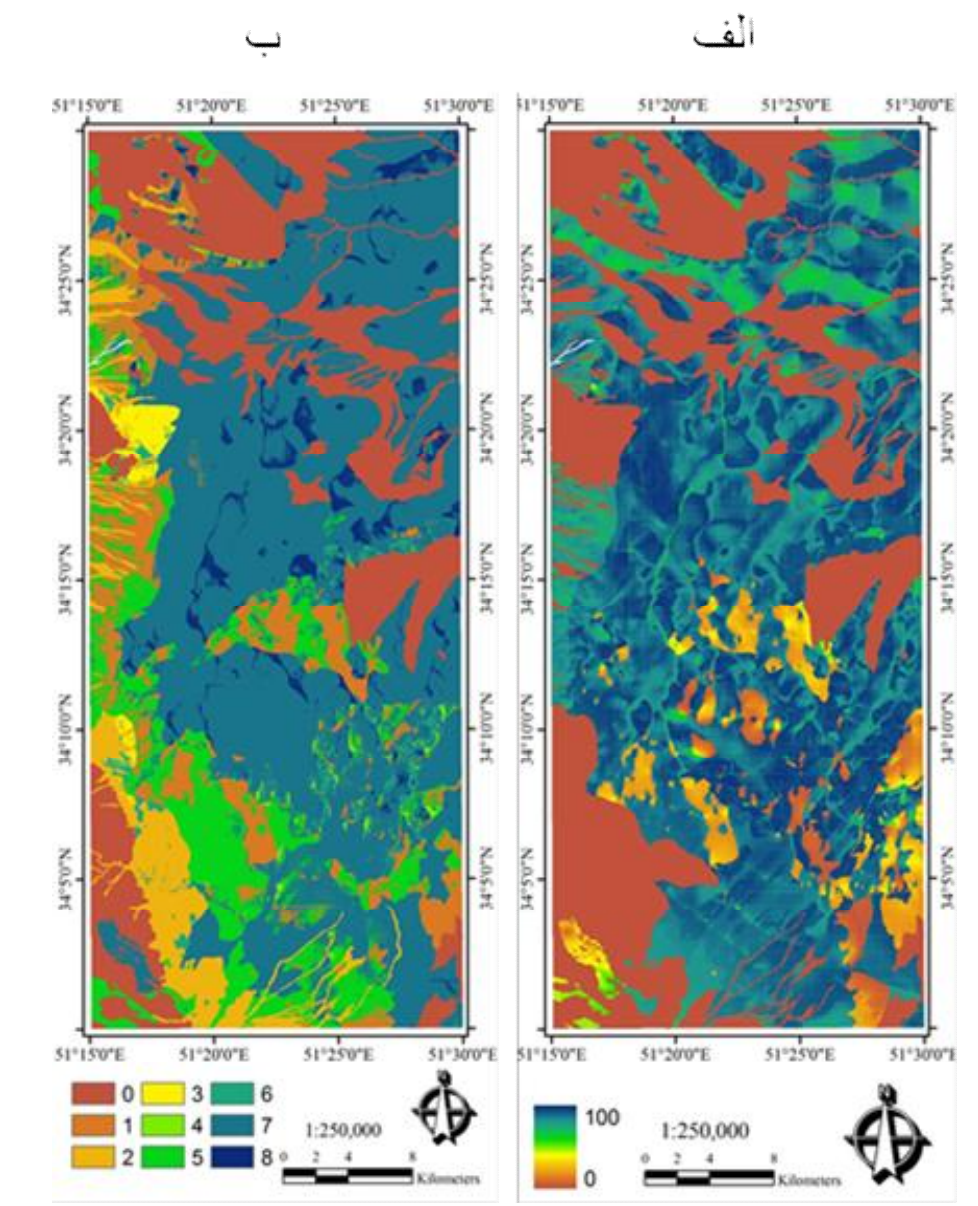

شكل ه. نقشه ييشبينى فازى براى خاك نوع V (كويى ساليدز): الف) در منطقه مورد مطالعه و نقشه بيش ينى نهايى (غيرفازى) و ب) منطقه مورد مطالعه

جدول r. ماتريس خطا (برحسب بيكسل) نقشه رقومى حاصل از مدل SOLIM براساس سطح زير رده براى تمامى خاى رخهاى منطقه مورد مطالعه

\begin{tabular}{|c|c|c|c|c|c|c|c|c|}
\hline كل & هاك نوع لهايلو ساليد & هاك هايلوزيّنسيدز & تورى نول نوع ه هنتز & تورى يسامنت نوع & خاك نوعَ اكوى ساليدز & هاى نوع & تورى اورتوع 1 & مشاهده شدهاط شده \\
\hline $4 \wedge$ & 。 & 。 & 。 & 。 & 。 & 。 & $\varphi \wedge 。$ & تورى اورتنتز \\
\hline TAV & $\circ$ & r & $\circ$ & 。 & 。 & $r 90$ & 。 & هايلو كلسيدز \\
\hline 019 & ro & 9 & TY & 。 & TYN & TY & 114 & اكوى ساليدز \\
\hline 91 & 。 & 。 & 。 & 91 & 。 & 。 & 。 & تورى يֶامنت \\
\hline ITA & 。 & 1 & 111 & V & 。 & r & 。 & تورى فلوئتز \\
\hline 190 & 。 & 190 & $\circ$ & 。 & 。 & 。 & 。 & ها يلوزييسيدز \\
\hline leto & $|4| 0$ & IV & 。 & 1 & 。 & 。 & 。 & هايلوساليد \\
\hline r.gr & lero & 190 & ler & $M$ & TYA & rq1 & 094 & كل \\
\hline
\end{tabular}


روش ها مىباشد. همانطور كه ملانو و همكاران roo9 با كاربرد

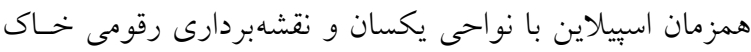

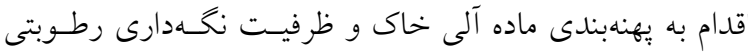
خاك در استراليا نمودند. سليمان و همكاران باهب در اندونزى

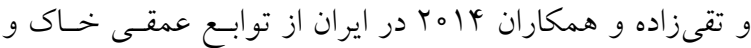

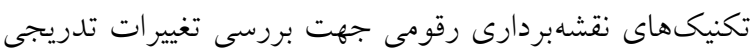

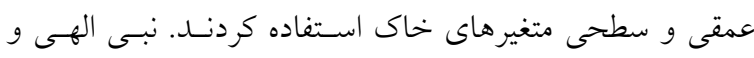

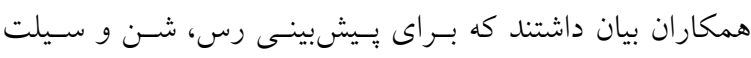

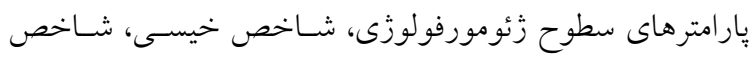

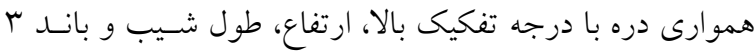

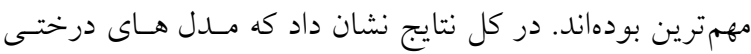
داراى دقت بالاترى نسبت به روش شبكه عصبى مصنوعى بوده و هم:جنين تفسير نتايج مدل درختى بسيار راحت تـر مسى باشـــ. همجنين تقىزاده و همكاران در تحقيقى در منطقه دورود استان

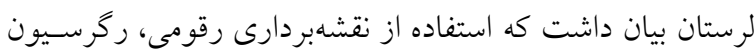

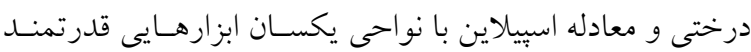

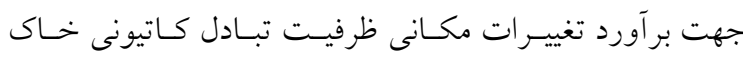
بلهصورت جانبى و عمقى مىباشند.

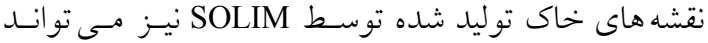
به طور قابل ملاحظهاى دقيقتر از همتاى مرسوم خود باشـــ. در

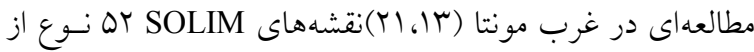
خاكها را از بو نمونه بهدرستى بيش بينى كرد (صحت ائراز). در حالى كه نقشه هاى بررسى هاى مرسوم خاك فقط هب نمونـه

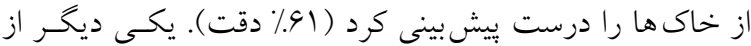
مطالعات در جنوب غربى وليسكاشين نتايج مشابهى را نشان داد نوع از 99 نوع خاك نمونه را به درستى بيشبينى

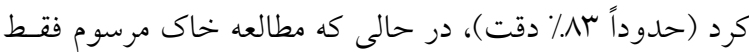
94 نوع از 99 خاك را به درستى بيش بينى كـرد (حسـود وVV)

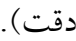

دقـت بــالاتر از محصــولات اطلاعــــ توليـــ شـــه از

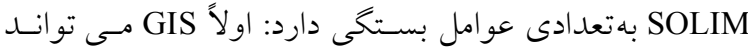
اطلاعات بسيار دقيق در مورد تغييرات شرايط محيطى را در بر بر بر
يلى گُون براساس واحد نقشه با يك يا دو نـوع خـاك نشـاندار

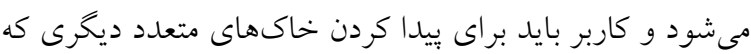

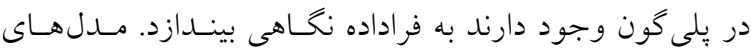

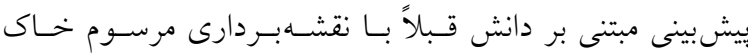

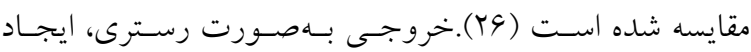

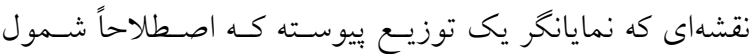

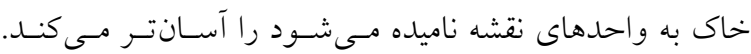
صحت و دقت دادههـاى رسـترى خـاك بـه صـحت دادههـاى

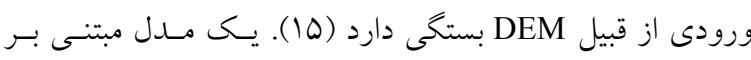

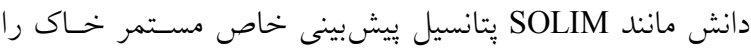

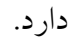

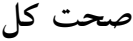
نقشسبــردارى رقـومى بــا ايجـاد بينشسى در مـورد فر آينـدهاى خاكسازى، باعث يِشرفت بالقوه بِدولوزى و جغرافيـاى خـاك مى شود (19). بايه و اساس نقشه بردارى رقومى خاكى مبتنى بـر معادله اسكورين مسى باشــ (4 () . بيشـاٍ و همكـاران 1999 كارايى بالاى تابع اسبيلاين عمقى را نسبت به ساير توابع عمـق

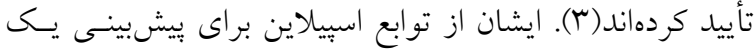
سرى از خصوصيات خاك از قبيل واكنش خاك، قابليت هدايت الكتريكى، درصد رس، ماده آلى خاك و ميزان رطوبت حجمسى

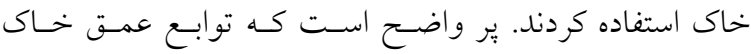
(اسييلاين با نواحى يكسان) بيشبينى خصوصسيات خـاك رادر

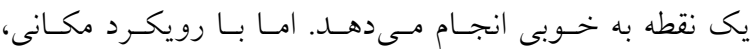

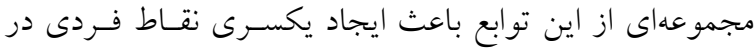
منطقه مى گردد. اما براى استفاده كند كان خاك شايد ايـن گونـهـ

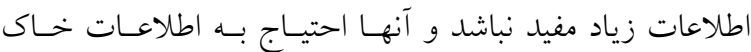

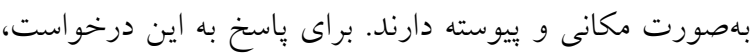

مى توان به نقشهبردارى رقومى خاك مراجعه كرد (14).

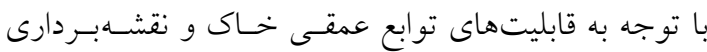

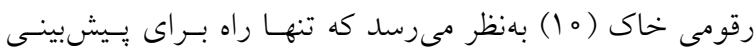
سطحى و عمقى خصوصسيات خـاك، اسـتفاده همزمـان از ايسن 
مدل، هر دو مربوط به يـك سـطح ردهبنـدى خـاص (مانتــ

زير گروه) باشند، در دسترس قرار مىدهد (1).

\section{نتيجه كيرى كلى}

استفاده از ويززگ هاى مختلف مدل رقومى ارتفاع كه هم به لحاظ منطقى و رياضى، و هم از نظر تجربسى داراى رابطـهُ نزديكى بــا

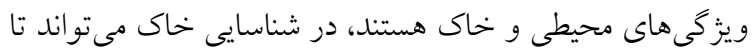
حد زيادى بر دقت كار بيفزايد و از صرف هزينه و زمان بـه كاهـــ. نتايج يزوهش حاضر نشان داد كه با اسـتفاده از شـش ويزگگى از مدل رقومى ارتفاع ونقشه زمين شناسـى و اطـلاع از خـاك هـاى لـاى غالب منطقه مى توان بــرآورد درستى از نقشـهـ رقــومى خـاك در سطح زير رده خاك با دقت وس/4 9 درصد بهدست آورد. در ايسن

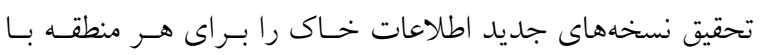
سرعت قابل قبولى توليد شدند. بهطورى كه برخلاف روش سنتى

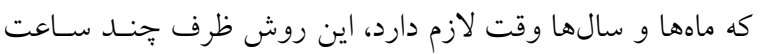
تا جند روز قادر به توليد اطلاعات و نقشههاى جديد اسـت و از آنجايى كه دادههاى ذخيـره شـده در سـامانه GIS و فــازى قابـل

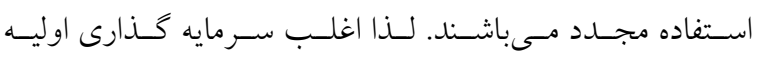
نقشهبردارى خاى يا روز آمــن كـردن آن ارزش خــود را حفـظ كرده بنابر اين هزينههاى روز آمد كردن بعدى كاهش مىيابد.
ختيار قرار مى دهد و از قابليتهاى بردازش دادههاى رقومى اين است كه اجازه مى دهد بسيارى از متغيرها بهطور همزمان درنظر كرفته شوند (ه广، צr). اين ممكن است تعـداد اجـزاء خاك و جلو گيرى از تغيير غلط نوع خـاى را كـاهش دهـد. دوماً SOLIM اجازه مى دهل تا شرايط خاى محلى در سـطح يِيكسل بيان شود، در نتيجهه ميزان تعميم فضايى كـهـ بـهـ طـور معمول در نقشه هاى مرسوم رخ مى دهد كاهش مى يابــ. در

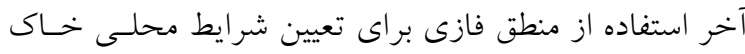
اجازه مى دهد تا خاك يك ييكسل از نظر شباهتش بـا انـواع خاك هاى مختلف نشان داده شود، بهجاى اينكه مجبور باشيم يكى موضوع واحد مجزا تعيين كنيم. بنابراين امكـان بــرآورد دقيقتر از شرايط خاك هر بييكسل وجود دارد. در مطالعسهاى ديخر در جنوب غربى بروجن بـاقرى بيـان داشـت ارزيـابى

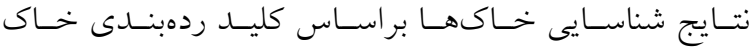
آمريكايى كه داراى معيارهاى سخت و صلب است، تا حدى مىتواند گمراه كننده باشد؛ حال آن كه استفاده از مدل فـازى كه تغييريذيرى تدريججى خاك هــا را مــ نظـر قـرار SOLIM مى دهل، نمود بهترى از واقعيت خاكها را بيان مسى كنــ (1). اجراى مــل SOLIM بـا دادههـايى كـه مربـوط بـه سـطوح پايين تر (مانند فاميل) ردهبندى خاك مى باشند و ارايسـة نتـايج براى سطوح بالاتر (مانند زيرگروه)، برآوردهـاى دقيـقتـر و بهترى را نسبت به زمـانى كـه دادههـاى ورودى و خروجـى

\section{منابع مورد استفاده}

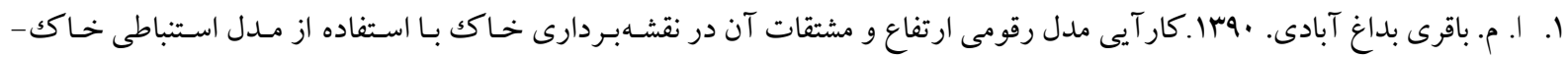

$$
\text { سرزمين (SoLIM) ، آب و خاكك (علوم و صنايع كشاورزى) هץ: 1111- 111. }
$$

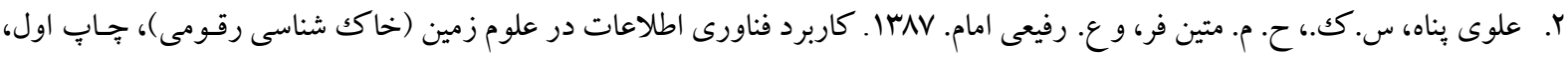

$$
\text { فصل دوم و سوم، انتشارات دانشگاه تهر ان. }
$$

3. Bishop T. F. A., A. B. McBratney and G. M. Laslett 1999. Modelling soil attribute depth functions with equal-area quadratic smoothing splines. Geoderma. J. 91: 27-45.

4. Boruvka L., Kozak J., Nemek J. and Penizec V. 2002. New approach to the exploitation of former soil survey data. 17th world Congress of Soil Science, 14- 21August, Bangkok, Thailand.

5. Burrough, P. A., R. A. MacMillan and W. van Deursen. 1992. Fuzzy classification methods for determining land suitability from soil profile observations and topography. Soil Sci. J. 43:193-210.

6. Cook, S. E., R. J. Corner, G. Grealish, P. E. Gessler and C. J Chartress. 1996.A rule-based system to map soil 
properties. Soil Sci. Am. J. 60: 1893-1900.

7. Grunwald, S. 2006. What do we really know about the space time continuum of soil- landscapes PP. 3-36. In: Grunwald, S. (Ed.), Environmental Soil Landscape Modeling, Geographic Information Technologies and Pedometrics. Taylor and Francis, New York.

8. Kempen, B., D. J. Brus, G. B. M. Heuvelink and J. J. Stoorvogel. 2009.Updating the 1:50 000 Dutch soil ma using legacy soil data: A multinomial logistic regression approach. Geoderma J. 151: 311-326.

9. Lagacherie P. and A. B. McBratney. 2007. Spatial soil information systems and spatial soil inference systems: perspectives for digital soil mapping. Digital soil mapping: An introductory perspective. Soil Sci. J. 31: 3-22.

10. Legros, J. P. 2006. Mapping of the soil. Science publishers, NH, USA, 411 PP.

11. Luo, Y. M., Z. G. Li, L. H. Wu, S. C. Wu, G. L. Zhang, S. L Zhou,. Y. G. Zhao, Q. G. Zhao, M. H. Wong and H. B. Zhang. 2007. Hong kong Soils and Environment (in Chinese). Science Press, Beijing.

12. Malone B. P., A. B. McBratney Minasny and G. M. Laslett 2009. Mapping continuous depth functions of soil carbon storage and available water capacity. Geoderma J. 154: 138-152.

13. McBratney A. B., M. L. Mendonça Santos and B. Minasny. 2003. On digital soil mapping. Geoderma. J. 117 : 3-52.

14. McKay, J. 2008. Using a Knowledge-Based System to Test the Transferability of a soil - Landscape Model in Northeastern Vermont. M. S. Thesis, Gainesville, Florida University.

15. McKay, J., S. Grunwald, X. Shi, R. F. Long. 2010. Evaluation of the Transferability of a knowledge-Based soilLandscape Model. Digital soil Mapping Progress in Soil Sci. J. 2: 165-178.

16. Pennock, D. J., B. J. Zebarth and E. dejong. 1987. Landform classification and soil distribution in Hummocky terrain, Saskatchewan, CA. Geoderma J. 40: 297-315.

17. Rossiter, D. G. 2000. Methodology for soil Resource Inventories and Revised Version, soil Science Division, International institute for Aerospace Survey \& Earth Science (ITC), 132 PP.

18. Scull, P. R. 2002.Predictive soil mapping in the Mojave Desert of California. Master degree Thesis, California University.

19. Sulaeman, Y., M. Sarwani, B. Minasny, A. B. McBratney, A. Sutandi and B. Barus. 2012. Soil-landscape models to predict soil $\mathrm{pH}$ variation in the Subang region of West Java. PP. 317-325. In: B. Minasny et al. (Ed.), Digital Soil Assessment and Beyond. CRC Press, Indonesia.

20. Smith, S. C., Buimer, E. Flager, G. Frank and D. Filatow. 2010. Digital soil mapping at multiple scales in British Columbia, Canada. In Program and Abstracts, $4^{\text {th }}$ Global Workshop on Digital Soil Mapping, 24-26 May, Rome, Italy.

21. Taghizadeh-Mehrjardi R., B. Minasny, F. Sarmadian and P. B. Malone. 2014. Digital mapping of soil salinity in Ardakan region, Cent. Iran. Geoderma J. 213: 15-28.

22. Webb T. H. and L. R. Lilburne. 2005. Consequence of soil map unit uncertainty on environmental risk assessment. Aust. Soil. Res. J. 43: 119-126.

23. Zhu, A. X., L. E. Band, B. Dutton and T. J. Nimlos. 1996. Automated Soil Inference Under Fuzzy Logic. Int. J. Ecol. Model. 90: 123-145.

24.Zhu, A. X., L. E. Band, R. Vertessy and B. Dutton. 1997. Derivation of soil properties using a soil land inference model (SoLIM). Soil Sci. Am. J. 61:523-533.

25. Zhu, A., B. Hudson, J. Burt, k. Lubich and D. Simonson. 2001. Soil mapping using GIS, expert knowledge and fuzzy logic. Soil Sci. Am. J. 65: 1463-1472. 


\title{
Evaluating Soil- Environment Inference Model (SOLIM) for Soil Mapping Based on Fuzzy Logic in Kashan
}

\author{
E. Mehrabi Gohari ${ }^{*}$, H. R. Matinfar ${ }^{2}$ and R. Taghizadeh ${ }^{3}$
}

(Received: Feb. 07-2015 ; Accepted: May 15-2017)

\begin{abstract}
Typical routine surveys of soils are relatively expensive in terms of time and cost and due to the fact that maps have been traditionally developed and considering their dependence on experts' opinions, updating maps is time consuming and sometimes not economical as well. While soil digital mapping, using soil various models - the Landscape, leads to simplification of the complexity found in natural soil systems and provides users with quick and inexpensive updates. In fact, the model represents a simplified form of the complex relationships between the soil and the land. This study aims to consider inferential model Soil-Land (SOLIM) in mapping and estimating soil classes in Aran area, Isfahan province. For this purpose, the SOLIM model inputs are digital geological and environmental layers of digital elevation model (DEM) including elevation, slope in percent, slop direction, curvature of the earth's surface, wetness indicator, flow direction, flow accumulation, and satellite images of Landsat 8. The seven subcategory of soil in the study area are input data of SOLIM model. Then fuzzy maps were prepared for seven types of soil and final maps of soil prediction were created by non-fuzzy action. Results showed that the SOLIM using environment variables has very high ability to separate soil types in greater detail and soils with different parent materials, geology, climate and vegetation can be separated from each other by this model with a high degree of accuracy. Comparing error matrix shows that the overall accuracy of the map derived from the model SOLIM is $92.36 \%$.
\end{abstract}

Keywords: soil mapping, digital elevation models, fuzzy logic, SOLIM model.

1. Faculty of Agric., Payame Noor Univ., Tehran, Iran.

2. Dept. of Soil Sci., Faculty of Agric, Lorestan Univ., Lorestan, Iran.

3. Dept. of Natural Resour., Faculty of Agric., Ardakan Univ., Ardakan, Iran.

*: Corresponding Author, Email: elham.mehrabi1@yahoo.com 